\title{
Yield, Water-, and Nitrogen-use Efficiency in Field-grown, Grafted Tomatoes
}

\author{
Desire Djidonou ${ }^{1}$, Xin Zhao ${ }^{2,4}$, Eric H. Simonne ${ }^{3}$, and Karen E. Koch ${ }^{3}$ \\ Horticultural Sciences Department, University of Florida, Gainesville, \\ FL 32611
}

\author{
John E. Erickson ${ }^{2}$ \\ Agronomy Department, University of Florida, Gainesville, FL 32611 \\ Additional index words. grafting, rootstock, scion, sandy soil, Solanum lycopersicum, \\ S. lycopersicum $\times S$. habrochaites
}

\begin{abstract}
In addition to managing soilborne diseases, grafting with vigorous rootstocks has been shown to improve yield in tomato (Solanum lycopersicum L.) production. However, the influence of different levels of nitrogen $(N)$ and irrigation supplies on grafted tomato plants has not been fully examined in comparison with non-grafted plants, especially under field conditions. The objective of this two-year study was to determine the effects of different irrigation regimes and $\mathrm{N}$ rates on yield, irrigation water use efficiency (iWUE), and N use efficiency (NUE) of grafted tomato plants grown with drip irrigation in sandy soils of north Florida. The determinate tomato cultivar Florida 47 was grafted onto two interspecific hybrid rootstocks, 'Beaufort' and 'Multifort' $(S$. lycopersicum $\times$ S. habrochaites S. Knapp \& D.M. Spooner). Non-grafted 'Florida 47' was used as a control. Plants were grown in a fumigated field under 12 combinations of two drip irrigation regimes $(50 \%$ and $100 \%$ of commonly used irrigation regime) and six $\mathrm{N}$ rates $\left(56,112,168,224,280\right.$, and $\left.336 \mathrm{~kg} \cdot \mathrm{ha}^{-1}\right)$. The field experiments were arranged in a split-plot design with four replications. The whole plots consisted of the irrigation regime and $\mathrm{N}$ rate combination treatments, whereas the subplots represented the two grafting treatments and the non-grafted plants. Self-grafted 'Florida 47' was also included in the $100 \%$ irrigation and $224 \mathrm{~kg} \mathrm{~N} / \mathrm{ha}$ fertilization treatment as a control. In 2010 , the $\mathbf{5 0 \%}$ irrigation regime resulted in higher total and marketable yields than the $100 \%$ irrigation regime. Tomato yield was significantly influenced by $N$ rates, but similar yields were achieved at $168 \mathrm{~kg} \cdot \mathrm{ha}^{-1}$ and above. Plants grafted onto 'Beaufort' and 'Multifort' showed an average increase of $27 \%$ and $30 \%$ in total and marketable fruit yields, respectively, relative to non-grafted plants. In 2011, fruit yields were affected by a significant irrigation by $\mathbf{N}$ rate interaction. Grafting significantly increased tomato yields, whereas grafted plants showed greater potential for yield improvement with increasing $\mathbf{N}$ rates compared with non-grafted plants. Self-grafting did not affect tomato yields. More fruit per plant and higher average fruit weight as a result of grafting were observed in both years. Grafting with the two rootstocks significantly improved the irrigation water and $\mathrm{N}$ use efficiency in tomato production. Results from this study suggested the need for developing irrigation and $\mathbf{N}$ fertilization recommendations for grafted tomato production in sandy soils.
\end{abstract}

Grafting is currently practiced worldwide on many high-value cucurbitaceous and solanaceous crops such as watermelon [Citrullus lanatus (Thunb.) Matsum. \& Nakai], melon

\footnotetext{
Received for publication 20 July 2012. Accepted for publication 19 Nov. 2012.

This research was funded in part by a Southern Region Sustainable Agriculture Research and Education (SARE) Graduate Student Grant (GS10-097). We thank Glenn Zalmann, Michael Alligood, and Bee Ling Poh for their technical assistance with the field experiment. We also thank Seminis Vegetable Seeds, Inc. and De Ruiter Seeds Inc. for providing the tomato seeds.

${ }^{1}$ Graduate Research Assistant.

${ }^{2}$ Asssitant Professor.

${ }^{3}$ Professor.

${ }^{4}$ To whom reprint requests should be addressed; e-mail zxin@ufl.edu.
}

(Cucumis melo L.), cucumber (Cucumis sativus L.), tomato (Solanum lycopersicum L.), eggplant (S. melongena L.), and pepper (Capsicum annuum $\mathrm{L}$.) for both open-field production and protected culture (Davis et al., 2008; Lee, 1994; Lee and Oda, 2003; Lee et al., 2010). Vegetable grafting has proven to be an innovative and effective technique for controlling soilborne diseases such as fusarium wilt (caused by Fusarium oxysporum), verticillium wilt (caused by Verticillium dahliae), southern blight (caused by Sclerotium rolfsii), and bacterial wilt (caused by Ralstonia solanacearum) (McAvoy et al., 2012; Rivard and Louws, 2008; Rivard et al., 2010, 2012) as well as root-knot nematodes (Meloidogyne spp.) (Barrett et al., 2012; Bausher, 2009; López-Pérez et al., 2006). Grafting with certain rootstocks has also been shown to improve plant tolerance to abiotic stresses such as high salt and low temperature
(Fernández-García et al., 2004; Schwarz et al., 2010).

Previous studies have demonstrated that in addition to disease management, plant vigor and yield often increase as a result of grafting with vigorous rootstocks. In the case of tomato production, grafted plants can increase marketable yield by $\approx 20 \%$ to $62 \%$ over non-grafted plants, depending on scionrootstock combinations and production conditions (Di Gioia et al., 2010; Lee and Oda, 2003; Leonardi and Giuffrida, 2006; Pogonyi et al., 2005). The improved productivity of grafted plants has been attributed by some studies to the intrinsic vigor of the rootstock and the scion-rootstock interaction, which in turn exerts positive influence on plant nutrient and water absorption, endogenous hormone balance, $\mathrm{N}$ assimilation, and photosynthetic processes (Aloni et al., 2010; Kato and Lou, 1989; Lee et al., 2010; Stegemann and Bock, 2009; Yamasaki et al., 1994). Given the physiological and phenotypic modifications caused by grafting with selected, vigorous rootstocks, it is likely that irrigation and fertilization management for maximizing crop yield may differ between grafted vs. non-grafted vegetable production.

In addition to the enhanced fruit yields with grafted plants, plants grafted onto vigorous rootstocks also use irrigation water and fertilizer more effectively for producing marketable fruit yields. Recent research has addressed the growth and yield performance of grafted plants in response to different levels of water or nutrients (Colla et al., 2010, 2011; Rouphael et al., 2008). However, most of these studies focused on cucurbits, especially under greenhouse conditions, with an emphasis on either irrigation or fertilization management rather than a combination of both. In the present study, responses to both nutrients and water are examined together and addressed by comparing grafted vs. non-grafted tomato production under field conditions. This information is important for aiding recommendations to producers who are increasingly adopting grafting for open-field tomato production on a larger scale. Furthermore, conditions in Florida, where the commercial production of fresh market tomato occurs, include sandy soils with low water and nutrient retention capacities (Hartz and Hochmuth, 1996; Hochmuth, 1992; Locascio, 2005). The situation in Florida is compounded by recommendations for $\mathrm{N}$ fertilization based primarily on crop type rather than soil tests (Olson et al., 2009). Therefore, the objectives of this study were to 1) determine the influence of irrigation regimes and $\mathrm{N}$ fertilizer application rates on yield and yield components of grafted tomato plants grown with drip irrigation in Florida sandy soils; and 2) characterize the influence of grafting with vigorous rootstocks on irrigation water and $\mathrm{N}$ use efficiency under these conditions.

\section{Materials and Methods}

Grafting and transplant production. The field-grown, determinate tomato cultivar Florida 47 (Seminis Vegetable Seeds, Inc., 
St. Louis, MO) was used as the scion and grafted onto two commercially available, interspecific hybrid rootstocks, 'Beaufort' and 'Multifort' (De Ruiter Seeds Inc., Bergschenhoek, The Netherlands). These two rootstocks are currently among the most widely used tomato rootstocks in the United States. Rootstock seeds were sown on 21 Feb. 2010 and 19 Feb. 2011, 2 d before the 'Florida 47' scion, to ensure similar stem diameters at the time of grafting because the rootstock cultivars tend to germinate and emerge more slowly. Plants were splice-grafted (Lee and Oda, 2003) on 16 Mar. 2010 and 20 Mar., 2011, when four to five true leaves were present. Grafted plants were immediately placed in a closed healing chamber equipped with two humidifiers and an auto-control air conditioning system for healing the grafts, where temperature was maintained at $25 \pm 3{ }^{\circ} \mathrm{C}$ and average relative humidity above $80 \%$. Light and ventilation were introduced gradually after a dark period of $4 \mathrm{~d}$. Twelve days after grafting, grafted plants including 'Florida 47' grafted onto 'Beaufort' (FL/BE) and 'Florida 47' grafted onto 'Multifort' (FL/MU) were completely healed and ready for transplanting to the field. Non-grafted 'Florida 47' (FL) transplants provided the control treatment.

Field production. The field experiments were conducted during the spring seasons of 2010 and 2011 at the Suwannee Valley Agricultural Extension Center in Live Oak, FL (lat. $30.31^{\circ} \mathrm{N}$, long. $82.90^{\circ} \mathrm{W}$ ). The soil type was a Blanton-Foxworth-Alpin Complex sandy soil (Natural Resources Conservation Service, 2006). In both years, field plots were disked and plowed, 5 weeks before transplanting, followed by soil fumigation using Telone C35 (Dow AgroSciences, LLC, Indianapolis, IN) at the rate of $196.4 \mathrm{~L} \cdot \mathrm{ha}^{-1}$. The field was fumigated to eliminate interference of soilborne pest factors. Mehlich-1 soil test results conducted before field preparation showed a high level of soil phosphorus (P) while a low level of soil potassium $(\mathrm{K})$. Three weeks before transplanting, 13N-1.7P-10.8K (Mayo Fertilizer Inc., Mayo, FL) fertilizer was applied at a rate providing $56 \mathrm{~kg} \mathrm{~N} / \mathrm{ha}, 7.3 \mathrm{~kg} \mathrm{P} / \mathrm{ha}$, and $46.5 \mathrm{~kg} \mathrm{~K} /$ ha to all plots during bed preparation. Grafted and non-grafted plants were transplanted to raised beds with plastic mulch and drip irrigation on 29 Mar. 2010 and 1 Apr. 2011. Beds were $0.71 \mathrm{~m}$ wide and spaced $1.52 \mathrm{~m}$ apart (from middle to middle) with $0.46-\mathrm{m}$ in-row spacing for open-field tomato production.

In both years, a split-plot design with four replications was used. The whole-plot treatments, i.e., 12 factorial combinations of two irrigation regimes and six $\mathrm{N}$ fertilization rates, were arranged in a randomized complete block design. The subplot treatments included the two grafting treatments FL/BE and FL/MU and the non-grafted 'Florida 47' (FL) as a control, all randomized within each whole plot. There were 12 plants for each treatment combination per replication in both 2010 and 2011. The two irrigation regimes included: 1) $100 \%$ irrigation regime based on the commonly used irrigation regime by commercial growers in Florida, i.e., 9354-37,416 L/ha/day depending on the crop stage; and 2) $50 \%$ irrigation regime corresponding to 4677 $18,708 \mathrm{~L} /$ ha/day depending on the crop stage. The six $\mathrm{N}$ fertilization rates were $56,112,168$, 224,280 , and $336 \mathrm{~kg} \cdot \mathrm{ha}^{-1}$, which represented $25 \%, 50 \%, 75 \%, 100 \%, 125 \%$, and $150 \%$, respectively, of the currently recommended total $\mathrm{N}$ application rate of $224 \mathrm{~kg} \mathrm{~N} / \mathrm{ha}$ (a preplant application at $56 \mathrm{~kg} \mathrm{~N} / \mathrm{ha}$ included) for field production of irrigated, round tomatoes in sandy soils in Florida (Olson et al., 2009). Except for the 56-kg N/ha rate, which only included a preplant application of $13 \mathrm{~N}-$ $1.7 \mathrm{P}-10.8 \mathrm{~K}$, ammonium nitrate $(34 \mathrm{~N}-0 \mathrm{P}-0 \mathrm{~K}$; Mayo Fertilizer Inc., Mayo, FL) was injected weekly through the drip tape starting 1 week after transplanting (WAT) to provide the remaining amount of $\mathrm{N}$ for other fertilization rate treatments. The weekly injected amounts of $\mathrm{N}$ for each of these five $\mathrm{N}$ fertilization rates during 1 to 2 WAT, 3 to 4 WAT, 5 to 11 WAT, 12 WAT, and 13 WAT, respectively, were as follows: 1) 3.0, 4.0, 5.0, 4.0, and 3.0 kg.ha ${ }^{-1}$; 2) $6.1,8.0,10.0,8.0$, and $6.1 \mathrm{~kg} \cdot \mathrm{ha}^{-1}$; 3 ) 9.1 , $12.0,15.0,12.0$, and $9.1 \mathrm{~kg} \cdot \mathrm{ha}^{-1}$; 4) 12.1, 16.0, 19.9, 16.0, and $12.1 \mathrm{~kg} \cdot \mathrm{ha}^{-1}$; and 5) 15.1, 20.0, 24.9, 20.0, and $15.1 \mathrm{~kg} \cdot \mathrm{ha}^{-1}$. Potassium chloride (Dyna Flo 0N-0P-15K; Chemical Dynamics Inc., Plant City, FL) was also applied through fertigation to provide each treatment with amount of K needed after accounting for the preplant application based on the soil test. The weekly injected amounts of $\mathrm{K}$ during the growing season were as follows: $11.8,9.3,14.3,9.3$, and $6.7 \mathrm{~kg} \cdot \mathrm{ha}^{-1}$ during 1 to 2 WAT, 3 to 4 WAT, 5 to 11 WAT, 12 WAT, and 13 WAT, respectively. The stake-and-weave method was used for trellising the tomato plants. Other cultural practices, including pest control, followed current recommendations for commercial field tomato production in Florida (Olson et al., 2009). Furthermore, daily rainfall data collected by a weather station of the Florida Automated Weather Network (FAWN) located at Live Oak (FAWN, 2011) were used to compare the 2010 and 2011 seasons in terms of rainfall distribution. It should be noted that in addition to the non-grafted 'Florida 47' (FL) controls, self-grafted scion plants (FL/FL) were added as a second set of controls. These were included in the $100 \%$ irrigation and $\mathrm{N}$ rate $(224 \mathrm{~kg} \mathrm{~N} / \mathrm{ha})$ plots to examine the effect of graft injury and initial growth reduction associated with the grafting process.

Yield, irrigation water use efficiency, and nitrogen use efficiency. Mature green tomato fruit and fruit at more advanced ripening stages were harvested from 10 plants in each treatment combination per replication. Fruit were picked 80 and $88 \mathrm{~d}$ after transplanting (DAT) in 2010, and 75, 85, and 92 DAT in 2011. They were then graded as extralarge, large, medium, and culls (small fruit and defective fruit). Fruit in each grade were counted and weighed. Total fruit yield, marketable fruit yield, average fruit weight, and average number of fruit per plant were calculated. Irrigation water use efficiency (iWUE) was estimated as the ratio of the marketable fruit yield to the amount of irrigation water applied during the production season. Nitrogen use efficiency (NUE) was estimated as the ratio of the marketable fruit yield to the amount of $\mathrm{N}$ supplied during the production season.

Statistical analyses. Data from the 2010 and 2011 experiments were analyzed separately. Analysis of variance was conducted using the GLIMMIX procedure of SAS Version 9.2 (SAS Institute, Cary, NC). Within each season, yield and yield components, iWUE, and NUE were analyzed with a model including main effects of irrigation regime, $\mathrm{N}$ fertilization rate, and grafting treatment. All models also included all possible interaction terms of these factors. An analysis of the conditional studentized residuals indicated no deviations from the normality and homoscedasticity assumptions, and therefore data transformation was not needed. Tukey's test $(\alpha=0.05)$ was used for multiple comparisons.

\section{Results}

Seasonal rainfall at the experimental site. Daily rainfall data collected by the weather station located at the research center in Live Oak were used to compare the seasonal rainfall between the 2010 and 2011 trials (FAWN, 2011). The rainfall pattern at the experimental site varied greatly between the 2010 and 2011 growing seasons (Fig. 1). Total rainfall during the growing season was $272 \mathrm{~mm}$ in 2010 and $157 \mathrm{~mm}$ in 2011 . Within the first 4 WAT, there was $\approx 12 \%$ higher rainfall in 2011 than in 2010. However, starting from Week 5 through Week 11, an increased amount of rainfall by $\approx 226 \%$ occurred in 2010 than in 2011, i.e., $186 \mathrm{~mm}$ in 2010 vs. $57 \mathrm{~mm}$ in 2011 .

Total and marketable fruit yields. Irrigation regime, $\mathrm{N}$ fertilization rate, and grafting all showed a significant influence on tomato fruit yields in both 2010 and 2011 experiments (Table 1). In the 2010 trial, the $50 \%$ irrigation regime resulted in higher total and marketable fruit yields compared with the $100 \%$ irrigation regime. Increases averaged $15 \%$ and $19 \%$, respectively (Table 2 ). Within the six $\mathrm{N}$ rates evaluated, total and marketable fruit yields were significantly improved when the $\mathrm{N}$ rate increased from 56 to $168 \mathrm{~kg} \cdot \mathrm{ha}^{-1}$. However, no significant differences were observed with $\mathrm{N}$ rates of $168 \mathrm{~kg} \cdot \mathrm{ha}^{-1}$ and above (Table 2). Grafting with the two rootstocks significantly improved the yields of 'Florida 47'. Averaged over the two rootstocks, the increase of total and marketable fruit yields relative to those of non-grafted 'Florida 47' reached $27 \%$ and $30 \%$, respectively (Table 2 ). It was noted that the yield improvement in grafted plants was more pronounced starting in the second harvest, especially with the use of 'Multifort' rootstock (data not shown).

For the 2011 trial, the effects of $\mathrm{N}$ rates on tomato yields were dependent on irrigation regime as reflected by the significant interaction of irrigation regime by $\mathrm{N}$ rate (Tables 1 and 3 ). With the $50 \%$ irrigation regime, the total and marketable yields at $56 \mathrm{~kg} \mathrm{~N} / \mathrm{ha}$ were significantly lower than those at higher $\mathrm{N}$ rates, but yields at $112 \mathrm{~kg} \mathrm{~N} / \mathrm{ha}$ and above 


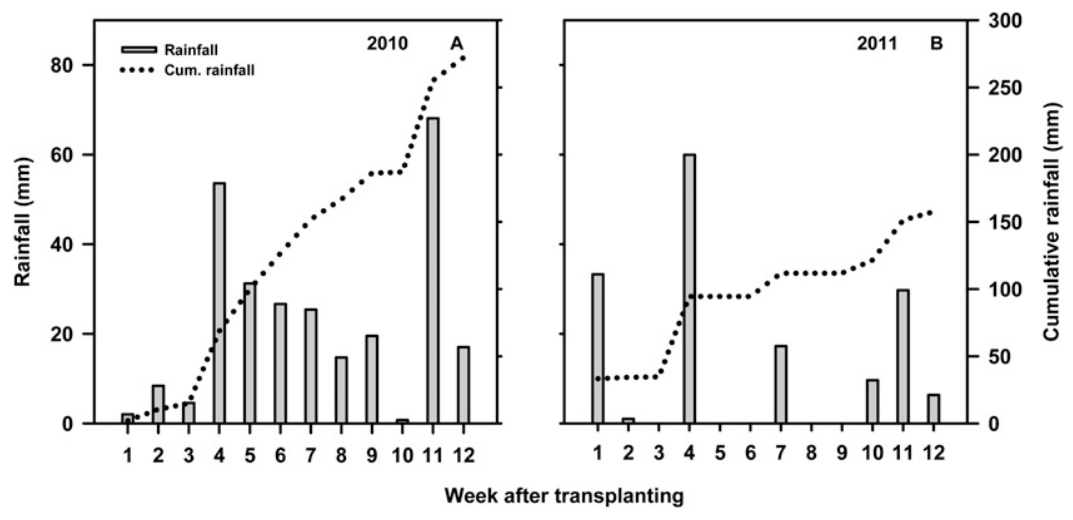

Fig. 1. Weekly and cumulative rainfall in Live Oak, FL, during the tomato field trials in 2010 (A) and 2011 (B). Data source: Florida Automated Weather Network (http://fawn.ifas.ufl.edu/). Tomato plants were transplanted on 29 Mar. 2010 and 1 Apr. 2011.

Table 1. Analysis of variance of the effects of irrigation regime (I), nitrogen $(\mathrm{N})$ fertilization rate, and grafting $(\mathrm{G})$ on total tomato fruit yield, marketable fruit yield, number of marketable fruit, average weight of marketable fruit, irrigation water use efficiency (iWUE), and nitrogen use efficiency (NUE) in the 2010 and 2011 field trials in Live Oak, FL.

\begin{tabular}{|c|c|c|c|c|c|c|c|c|c|c|c|c|c|}
\hline \multirow[b]{3}{*}{ Effect } & \multirow[b]{3}{*}{$\mathrm{df}$} & \multirow{2}{*}{\multicolumn{2}{|c|}{$\begin{array}{c}\text { Total } \\
\text { fruit yield }\end{array}$}} & \multirow{2}{*}{\multicolumn{2}{|c|}{$\begin{array}{l}\text { Marketable } \\
\text { fruit yield }\end{array}$}} & \multicolumn{4}{|c|}{ Marketable fruit } & \multirow{2}{*}{\multicolumn{2}{|c|}{ iWUE }} & \multirow{2}{*}{\multicolumn{2}{|c|}{ NUE }} \\
\hline & & & & & & \multicolumn{2}{|c|}{$\begin{array}{c}\text { Number of } \\
\text { fruit per plant }\end{array}$} & \multicolumn{2}{|c|}{$\begin{array}{l}\text { Avg } \\
\text { fruit wt }\end{array}$} & & & & \\
\hline & & 2010 & 2011 & 2010 & 2011 & 2010 & 2011 & 2010 & 2011 & 2010 & 2011 & 2010 & 2011 \\
\hline $\bar{I}$ & 1 & $* * *$ & ** & *** & ** & $* * *$ & NS & $* *$ & ** & ** & $* * *$ & *** & NS \\
\hline $\mathrm{N}$ & 5 & $* * *$ & $* * *$ & $* * *$ & $* * *$ & $* * *$ & $* * *$ & $* * *$ & $* *$ & $* * *$ & $* * *$ & $* * *$ & $* * *$ \\
\hline G & 2 & $* * *$ & $* * *$ & $* * *$ & $* * *$ & $* * *$ & $* * *$ & $* * *$ & $* * *$ & $* * *$ & $* * *$ & $* * *$ & $* * *$ \\
\hline $\mathrm{I} \times \mathrm{N}$ & 5 & NS & $* * *$ & NS & $* * *$ & $*$ & $* *$ & NS & NS & $* * *$ & $* *$ & NS & $*$ \\
\hline $\mathrm{I} \times \mathrm{G}$ & 2 & NS & NS & NS & NS & NS & NS & NS & $*$ & $* *$ & $* * *$ & NS & NS \\
\hline $\mathrm{N} \times \mathrm{G}$ & 10 & NS & NS & NS & * & NS & NS & * & * & * & $* *$ & * & NS \\
\hline $\mathrm{I} \times \mathrm{N} \times \mathrm{G}$ & 10 & NS & NS & NS & NS & NS & NS & NS & $* *$ & NS & NS & NS & NS \\
\hline
\end{tabular}

Ns, $* * *, * * *$ Nonsignificant or significant at $P \leq 0.05,0.01$, or 0.001 , respectively.

Table 2. Main effects of irrigation regime, nitrogen (N) fertilization rate, and grafting on total and marketable yields of 'Florida 47' tomato in the 2010 field trial in Live Oak, FL.

\begin{tabular}{llc}
\hline & \multicolumn{2}{c}{ Yield $\left(\mathrm{Mg} \cdot \mathrm{ha}^{-1}\right)$} \\
\cline { 2 - 3 } Treatment & Total & Marketable \\
\hline Irrigation (\%) & & \\
50 & $55.5 \mathrm{a}^{\mathrm{z}}$ & $49.8 \mathrm{a}$ \\
100 & $48.3 \mathrm{~b}$ & $41.8 \mathrm{~b}$ \\
N rate $\left(\mathrm{kg}^{\circ} \cdot \mathrm{ha}^{-1}\right)$ & & \\
56 & $23.4 \mathrm{c}$ & $18.4 \mathrm{c}$ \\
112 & $42.8 \mathrm{~b}$ & $36.3 \mathrm{~b}$ \\
168 & $57.0 \mathrm{a}$ & $49.9 \mathrm{a}$ \\
224 & $63.8 \mathrm{a}$ & $57.4 \mathrm{a}$ \\
280 & $61.9 \mathrm{a}$ & $55.4 \mathrm{a}$ \\
336 & $62.5 \mathrm{a}$ & $57.5 \mathrm{a}$ \\
Graft & & \\
FL/BE & $54.7 \mathrm{a}$ & $48.9 \mathrm{a}$ \\
FL/MU & $56.9 \mathrm{a}$ & $50.5 \mathrm{a}$ \\
FL & $44.1 \mathrm{~b}$ & $38.1 \mathrm{~b}$ \\
\hline
\end{tabular}

${ }^{2}$ Means within a column and a treatment category followed by the same letter do not differ significantly at $P \leq 0.05$ according to Tukey's test.

$\mathrm{FL} / \mathrm{BE}=$ 'Florida 47' grafted onto 'Beaufort'; FL/ $\mathrm{MU}=$ 'Florida 47' grafted onto 'Multifort'; $\mathrm{FL}=$ nongrafted 'Florida 47 '.

did not differ significantly. In contrast, under the $100 \%$ irrigation regime, significant yield increases were observed as the $\mathrm{N}$ rates increased. The total yield at $280 \mathrm{~kg} \mathrm{~N} /$ ha was significantly higher than those at lower $\mathrm{N}$ rates but did not differ significantly from that at $336 \mathrm{~kg} \mathrm{~N} / \mathrm{ha}$. A similar trend was found for the marketable yield, which reached the highest level at $280 \mathrm{~kg} \mathrm{~N} / \mathrm{ha}$, whereas it did not show significant differences from those at 224 and $336 \mathrm{~kg} \mathrm{~N} / \mathrm{ha}$ (Table 3 ). Comparison of the yield response to the two irrigation regimes at each $\mathrm{N}$ rate did not show a clear pattern; however, total yields did not differ except at 56 and $280 \mathrm{~kg} \mathrm{~N} / \mathrm{ha}$, whereas marketable yields were similar except at 280 and $336 \mathrm{~kg}$ $\mathrm{N} / \mathrm{ha}$. Similar to the 2010 experiment, total and marketable fruit yields of the grafted plants (FL/BE and FL/MU) were significantly higher than the non-grafted plants (FL) in the 2011 trial, and a significant grafting $\times \mathrm{N}$ rate interaction was also observed for marketable fruit yield (Tables 1 and 3). Grafting increased the marketable yield of 'Florida 47' with each $\mathrm{N}$ rate at or above $112 \mathrm{~kg} \mathrm{~N} / \mathrm{ha}$, and the yield increase reached $46 \%$ at $224 \mathrm{~kg} \mathrm{~N} / \mathrm{ha}$, the currently recommended $\mathrm{N}$ rate for non-grafted 'Florida 47'. Grafting also altered the effects of $\mathrm{N}$ rates on marketable yield. For example, for non-grafted 'Florida 47', marketable yield at $112 \mathrm{~kg} \mathrm{~N} /$ ha was significantly higher than that at $56 \mathrm{~kg} \mathrm{~N} / \mathrm{ha}$, but it did not show any significant increase at higher $\mathrm{N}$ rates. In contrast, the marketable fruit yields of the grafted plants exhibited a significant increase at $280 \mathrm{~kg} \mathrm{~N} /$ ha compared with those at 56 and $112 \mathrm{~kg} \mathrm{~N} /$ ha (Table 3).

Yield components. The marketable yield components, including number of tomato fruit per plant and average fruit weight, were further examined to identify the contributors to yield responses. In both 2010 and 2011 trials, grafted plants (FL/BE and FL/MU) had significantly more marketable fruit per plant than did non-grafted plants (FL) (Table 1). Grafting increased fruit number by an average of $13 \%$ in 2010 and $27 \%$ in 2011 (data not shown). The number of marketable fruit per plant was also affected by a significant interaction between irrigation regime and $\mathrm{N}$ rate in both years (Table 1). In 2010, under the $100 \%$ irrigation regime, the marketable fruit number per plant was significantly lower at $112 \mathrm{~kg} \mathrm{~N} / \mathrm{ha}$, and most reduced at $56 \mathrm{~kg}$ $\mathrm{N} /$ ha (Table 4). Under the $50 \%$ irrigation regime, fruit number was lowest at $56 \mathrm{~kg} \mathrm{~N} / \mathrm{ha}$ and was significantly increased at $112 \mathrm{~kg} \mathrm{~N} / \mathrm{ha}$, whereas increasing $\mathrm{N}$ rate beyond $112 \mathrm{~kg} \cdot \mathrm{ha}^{-1}$ significantly increased the fruit number at 224 and $336 \mathrm{~kg} \mathrm{~N} / \mathrm{ha}$. In the 2011 trial, the marketable fruit number at different $\mathrm{N}$ rates under the two irrigation regimes followed the same response of marketable fruit yields (Tables 3 and 4).

Consistent with the higher marketable yield under the 50\% irrigation regime in 2010, the average fruit weight was also significantly greater. Significant effects of grafting, $\mathrm{N}$ rate, and their interaction were also evident in average fruit weight (Table 1). Grafting with the two rootstocks significantly increased the average fruit weight of 'Florida 47' at most $\mathrm{N}$ rates tested but not at $112 \mathrm{~kg} \cdot \mathrm{ha}^{-1}$ (data for 2010 not shown). In the 2011 experiment, the impact of grafting on average fruit weight also reflected significant interaction effects associated with irrigation regime and $\mathrm{N}$ rate (Table 1). Under the 50\% irrigation regime, grafted plants (FL/BE and/or FL/MU) showed significantly greater average fruit weight than the non-grafted plants at each of the six $\mathrm{N}$ rates applied. In contrast, under the $100 \%$ irrigation regime, the average fruit weight did not differ between grafted and non-grafted 'Florida 47' at $56 \mathrm{~kg} \mathrm{~N} / \mathrm{ha}$ (Table 5). Under the recommended irrigation regime $(100 \%)$ and $\mathrm{N}$ rate $\left(224 \mathrm{~kg} \cdot \mathrm{ha}^{-1}\right)$, the average marketable fruit weight was increased by grafting by appropriately $17 \%$ in contrast to the non-grafted plants.

Irrigation water use efficiency. The iWUE relative to marketable fruit yields was affected by significant two-way interactions among grafting, irrigation regime, and $\mathrm{N}$ rate. $\mathrm{Re}-$ sults were similar in the 2010 and 2011 trials (Table 1). In both years, a marked decline of iWUE was observed when the irrigation regime was increased from $50 \%$ to $100 \%$ irrespective of grafting and $\mathrm{N}$ rate treatments (Fig. 2A-D). In 2010, the highest value of iWUE was achieved at 224 and $280 \mathrm{~kg} \mathrm{~N} / \mathrm{ha}$ within the $50 \%$ and $100 \%$ irrigation regimes, respectively, whereas it did not differ significantly between $\mathrm{N}$ rates at and above 168 $\mathrm{kg} \cdot \mathrm{ha}^{-1}$ within each irrigation regime. The iWUE at $112 \mathrm{~kg} \mathrm{~N} / \mathrm{ha}$ was significantly higher than that at $56 \mathrm{~kg} \mathrm{~N} / \mathrm{ha}$ under the $50 \%$ irrigation regime; however, such a difference was not observed under the $100 \%$ irrigation regime (Fig. 2A). In 2011, under the $50 \%$ irrigation regime, the iWUE at 112 $\mathrm{kg} \mathrm{N} /$ ha was significantly higher than that at 
Table 3. Total and marketable yields of 'Florida 47' tomato as influenced by interactions between irrigation regime, nitrogen $(\mathrm{N})$ fertilization rate, and grafting in the 2011 field trial in Live Oak, FL.

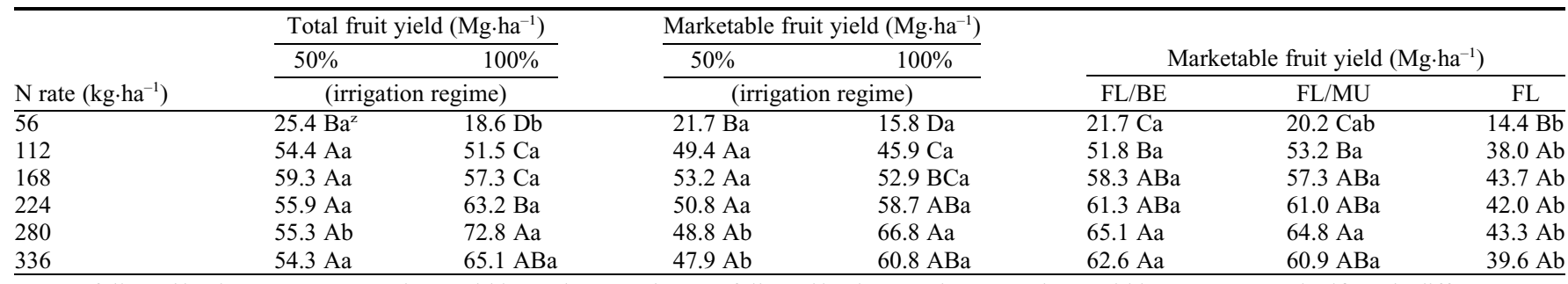

${ }^{\mathrm{z}}$ Means followed by the same uppercase letter within a column, and means followed by the same lowercase letter within a row are not significantly different at $P \leq$ 0.05 according to Tukey's test.

$\mathrm{FL} / \mathrm{BE}=$ 'Florida 47' grafted onto 'Beaufort'; FL/MU = 'Florida 47' grafted onto 'Multifort'; FL = non-grafted 'Florida 47'.

Table 4. Number of marketable tomato fruit per plant as influenced by interaction between irrigation regime and nitrogen (N) fertilization rate in the 2010 and 2011 field trials in Live Oak, FL.

\begin{tabular}{|c|c|c|c|c|}
\hline \multirow[b]{3}{*}{$\mathrm{N}$ rate $\left(\mathrm{kg} \cdot \mathrm{ha}^{-1}\right)$} & \multicolumn{2}{|c|}{2010} & \multicolumn{2}{|c|}{2011} \\
\hline & \multicolumn{2}{|c|}{ Irrigation regime $(\%)$} & \multicolumn{2}{|c|}{ Irrigation regime $(\%)$} \\
\hline & 50 & 100 & 50 & 100 \\
\hline 56 & $8 \mathrm{Ca}^{\mathrm{z}}$ & $7 \mathrm{Ba}$ & $9 \mathrm{Ba}$ & $7 \mathrm{Da}$ \\
\hline 112 & $16 \mathrm{Ba}$ & $12 \mathrm{Bb}$ & $19 \mathrm{Aa}$ & $17 \mathrm{Ca}$ \\
\hline 168 & $19 \mathrm{ABa}$ & $18 \mathrm{Aa}$ & $20 \mathrm{Aa}$ & $19 \mathrm{BCa}$ \\
\hline 224 & $22 \mathrm{Aa}$ & $18 \mathrm{Aa}$ & $20 \mathrm{Aa}$ & $21 \mathrm{ABa}$ \\
\hline 280 & $19 \mathrm{ABa}$ & $20 \mathrm{Aa}$ & $19 \mathrm{Ab}$ & $23 \mathrm{Aa}$ \\
\hline 336 & $22 \mathrm{Aa}$ & $18 \mathrm{Aa}$ & $18 \mathrm{Ab}$ & $22 \mathrm{ABa}$ \\
\hline
\end{tabular}

${ }^{\mathrm{z}}$ Means followed by the same uppercase letter within a column, and means followed by the same lowercase letter within a row are not significantly different at $P \leq 0.05$ according to Tukey's test.

Table 5. Average weight of marketable tomato fruit from grafted and non-grafted 'Florida 47' plants as influenced by interaction between irrigation regime and nitrogen $(\mathrm{N})$ fertilization rate in the 2011 field trial in Live Oak, FL.

\begin{tabular}{|c|c|c|c|}
\hline \multirow[b]{2}{*}{$\mathrm{N}$ rate $\left(\mathrm{kg} \cdot \mathrm{ha}^{-1}\right)$} & \multicolumn{3}{|c|}{ Avg fruit wt ( $g /$ fruit) } \\
\hline & Graft & $50 \%$ irrigation regime & $100 \%$ irrigation regime \\
\hline \multirow[t]{3}{*}{$\overline{56}$} & FL/BE & $165.2 \mathrm{ab}^{\mathrm{z}}$ & $161.7 \mathrm{a}$ \\
\hline & FL/MU & $177.1 \mathrm{a}$ & $159.2 \mathrm{a}$ \\
\hline & FL & $154.0 \mathrm{~b}$ & $170.9 \mathrm{a}$ \\
\hline \multirow[t]{3}{*}{112} & FL/BE & $182.7 \mathrm{a}$ & $190.6 \mathrm{a}$ \\
\hline & $\mathrm{FL} / \mathrm{MU}$ & $185.6 \mathrm{a}$ & $203.1 \mathrm{a}$ \\
\hline & FL & $165.6 \mathrm{~b}$ & $174.3 \mathrm{~b}$ \\
\hline \multirow[t]{3}{*}{168} & FL/BE & $188.7 \mathrm{ab}$ & $192.7 \mathrm{ab}$ \\
\hline & FL/MU & $189.6 \mathrm{a}$ & $210.6 \mathrm{a}$ \\
\hline & FL & $174.7 \mathrm{~b}$ & $175.2 \mathrm{~b}$ \\
\hline \multirow[t]{3}{*}{224} & FL/BE & $192.8 \mathrm{a}$ & $201.2 \mathrm{a}$ \\
\hline & $\mathrm{FL} / \mathrm{MU}$ & $178.3 \mathrm{ab}$ & $200.1 \mathrm{a}$ \\
\hline & FL & $166.6 \mathrm{~b}$ & $171.5 \mathrm{~b}$ \\
\hline \multirow[t]{3}{*}{280} & FL/BE & $193.6 \mathrm{a}$ & $190.9 \mathrm{~b}$ \\
\hline & $\mathrm{FL} / \mathrm{MU}$ & $182.0 \mathrm{a}$ & $211.5 \mathrm{a}$ \\
\hline & FL & $157.0 \mathrm{~b}$ & $195.0 \mathrm{~b}$ \\
\hline \multirow[t]{3}{*}{336} & $\mathrm{FL} / \mathrm{BE}$ & $190.1 \mathrm{a}$ & $202.5 \mathrm{a}$ \\
\hline & FL/MU & $190.3 \mathrm{a}$ & $194.3 \mathrm{ab}$ \\
\hline & FL & $156.9 \mathrm{~b}$ & $180.2 \mathrm{~b}$ \\
\hline
\end{tabular}

${ }^{\mathrm{z}}$ Means followed by the same letter within a column within the same $\mathrm{N}$ fertilization rate are not significantly different at $P \leq 0.05$ according to Tukey's test.

$\mathrm{FL} / \mathrm{BE}=$ 'Florida 47' grafted onto 'Beaufort'; FL/MU = 'Florida 47' grafted onto 'Multifort'; FL = nongrafted 'Florida 47'.

$56 \mathrm{~kg} \mathrm{~N} / \mathrm{ha}$, but the $\mathrm{N}$ rates above $112 \mathrm{~kg} \cdot \mathrm{ha}^{-1}$ did not lead to any significant increase of iWUE. Within the $100 \%$ irrigation regime, the iWUE reached the highest value at $280 \mathrm{~kg}$ $\mathrm{N} / \mathrm{ha}$, but it did not differ significantly from values at 224 and $336 \mathrm{~kg} \mathrm{~N} / \mathrm{ha}$ (Fig. 2B). Furthermore, iWUE of the grafted plants was significantly higher relative to that of nongrafted plants at both irrigation regimes in both years, although the difference tended to vary with the irrigation regime (Fig. 2C-D). In 2010, the averaged iWUE values of the in grafted plants but not in non-grafted 'Florida 47', especially in 2010. Increasing the $\mathrm{N}$ rate from 224 to $336 \mathrm{~kg} \cdot \mathrm{ha}^{-1}$ did not result in any pronounced change of iWUE. Furthermore, the performance of the two rootstocks used also seemed to differ at certain $\mathrm{N}$ rates. In both years, grafting significantly enhanced the iWUE at different $\mathrm{N}$ rates except that there was no significant difference between the iWUE of FL/MU and $\mathrm{FL}$ at $56 \mathrm{~kg} \mathrm{~N} / \mathrm{ha}$, whereas FL/BE and FL showed similar levels of iWUE at $168 \mathrm{~kg} \mathrm{~N} / \mathrm{ha}$ in 2010 .

Nitrogen use efficiency. In the 2010 trial, the main effect of irrigation regime was significant, whereas the significant effect of $\mathrm{N}$ rate on NUE was dependent on grafting (Table 1). NUE was $20 \%$ higher in the $50 \%$ irrigation regime compared with the $100 \%$ irrigation regime (data not shown). Moreover, compared with the non-grafted 'Florida 47', grafted plants with the two rootstocks enhanced NUE significantly at each $\mathrm{N}$ rate except the $168 \mathrm{~kg} \mathrm{~N} /$ ha treatment (Table 6). On average, the increase in NUE resulting from grafting with the vigorous rootstocks were $81 \%$ and $23 \%$ with the 56 and $112 \mathrm{~kg} \mathrm{~N} / \mathrm{ha}$, respectively, while ranging from $26 \%$ to $38 \%$ when increasing the $\mathrm{N}$ rate from 224 to $336 \mathrm{~kg} \cdot \mathrm{ha}^{-1}$. In addition, for both FL/BE and FL/MU, increasing the $\mathrm{N}$ rate from 56 to $336 \mathrm{~kg} \cdot \mathrm{ha}^{-1}$ consistently decreased the NUE. However, the decrease was mainly significant between the two lower $\mathrm{N}$ rates $\left(56\right.$ and $\left.112 \mathrm{~kg} \cdot \mathrm{ha}^{-1}\right)$ and the two higher $\mathrm{N}$ rates ( 280 and $336 \mathrm{~kg} \cdot \mathrm{ha}^{-1}$ ). With the non-grafted plants, NUE was significantly reduced at 280 and $336 \mathrm{~kg} \mathrm{~N} / \mathrm{ha}$ compared with those at 112 to $168 \mathrm{~kg} \cdot \mathrm{ha}^{-1}$. Furthermore, in 2011, the main effect of grafting was significant, whereas the significant effect of $\mathrm{N}$ rate on NUE was related to the irrigation regime (Table 1). In 2011, grafted plants with the two rootstocks increased NUE by $42 \%$ relative to that of non-grafted plants (data not shown). Under both irrigation regimes regardless of the grafting treatment, the rate of $112 \mathrm{~kg} \mathrm{~N} /$ ha resulted in the highest NUE, whereas the lowest NUE was observed at $336 \mathrm{~kg} \mathrm{~N} / \mathrm{ha}$ (Table 6). NUE values at certain $\mathrm{N}$ rates were also influenced by the irrigation regimes. At $56 \mathrm{~kg} \mathrm{~N} / \mathrm{ha}$, the NUE was significantly higher under the $50 \%$ irrigation regime, whereas the opposite was observed at each of the higher N rates $224 \mathrm{~kg} \cdot \mathrm{ha}^{-1}$ or greater. 


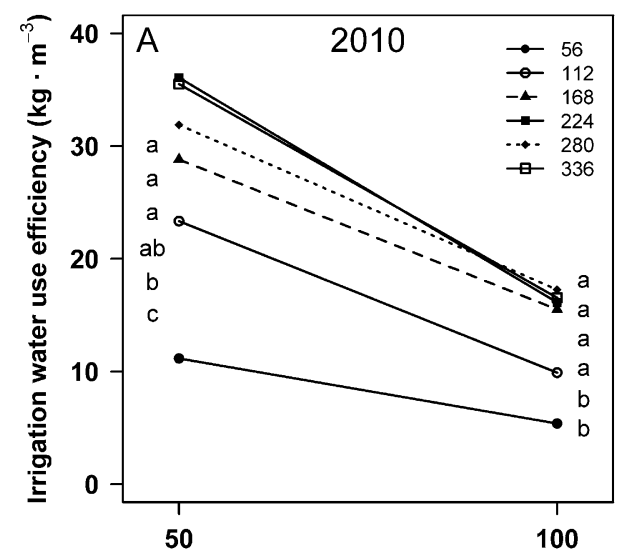

Irrigation regime (\%)
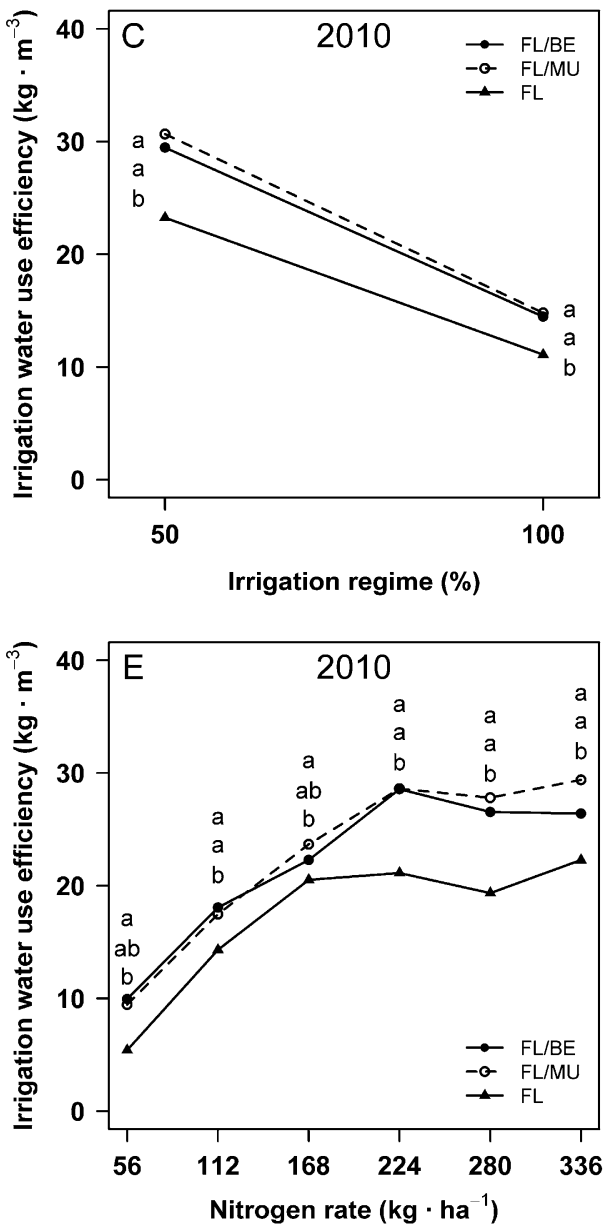

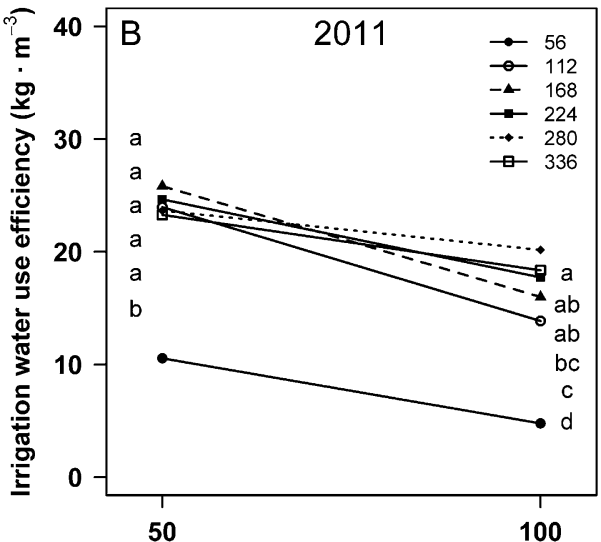

Irrigation regime (\%)
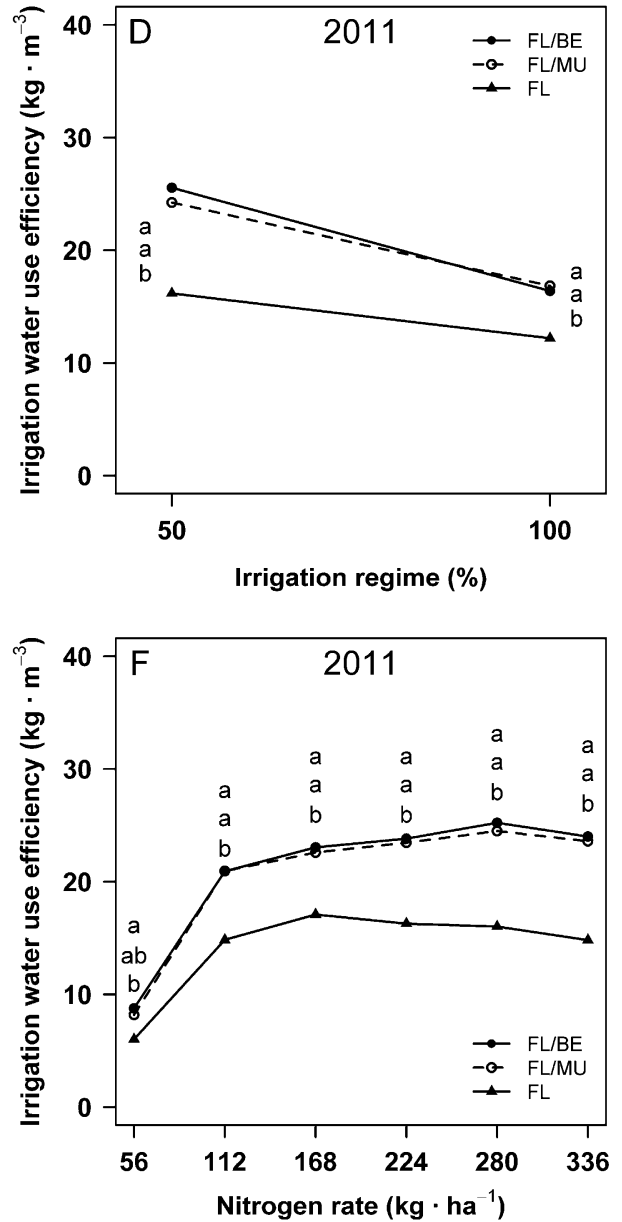

Fig. 2. Irrigation water use efficiency (iWUE) as influenced by interaction between irrigation regime and nitrogen (N) fertilization rate (A-B), by interaction between irrigation regime and grafting $(\mathbf{C}-\mathbf{D})$, and by interaction between $\mathrm{N}$ fertilization rate and grafting $(\mathbf{E}-\mathbf{F})$ in 2010 and 2011 , respectively. Irrigation water use efficiency was estimated as the ratio of the marketable fruit yield to the amount of irrigation water applied during the production season. Treatment values at each irrigation regime or each $\mathrm{N}$ fertilization rate followed by the same letter are not significantly different at $P \leq 0.05$ according to Tukey's test. FL/ $\mathrm{BE}=$ 'Florida 47' grafted onto 'Beaufort'; FL/MU = 'Florida 47' grafted onto 'Multifort'; FL = non-grafted 'Florida 47'.

\section{Discussion}

Grafting influence on fruit yields of tomato under field conditions. Grafting the determinate 'Florida 47 ' tomato plants with vigorous rootstocks 'Beaufort' and 'Multifort' significantly improved total and marketable fruit yields at almost all $\mathrm{N}$ rates applied in this study. Moreover, grafted plants tended to show greater potential for yield improvement with the increase of $\mathrm{N}$ than non-grafted plants, particularly in the 2011 trial. Compared with non-grafted tomato plants, it is likely that grafted plants may require a higher level of $\mathrm{N}$ for maximizing yield performance. Fruit is an important sink for carbohydrates and amino acids in tomato plants (Valle et al., 1998). Given the greater number of fruit per plant and higher average fruit weight of grafted plants, the sink strength of the grafted plants would have been at a higher level relative to that of the non-grafted plants. This stronger fruit sink of grafted tomato may partly reflect a greater demand for nutrients, especially N. Future work is warranted to elucidate the nutrient requirement for field production of grafted tomatoes with different 
Table 6. Nitrogen (N) use efficiency ${ }^{z}$ of 'Florida 47 ' tomato plants as influenced by interaction between $\mathrm{N}$ fertilization rate and grafting in the 2010 field trial and interaction between irrigation regime and $\mathrm{N}$ fertilization rate in the 2011 field trial in Live Oak, FL.

\begin{tabular}{|c|c|c|c|c|c|}
\hline \multirow[b]{4}{*}{$\mathrm{N}$ rate $\left(\mathrm{kg} \cdot \mathrm{ha}^{-1}\right)$} & \multicolumn{5}{|c|}{ Nitrogen use efficiency $\left(\mathrm{kg} \cdot \mathrm{kg}^{-1}\right)$} \\
\hline & \multicolumn{3}{|c|}{2010} & \multicolumn{2}{|c|}{2011} \\
\hline & \multicolumn{3}{|c|}{ Graft } & \multicolumn{2}{|c|}{ Irrigation regime $(\%)$} \\
\hline & FL/BE & FL/MU & $\overline{F L}$ & 50 & 100 \\
\hline 56 & $382.88 \mathrm{Aa}^{y}$ & $388.06 \mathrm{Aa}$ & $212.89 \mathrm{ABb}$ & $388.54 \mathrm{ABa}$ & $282.33 \mathrm{Bb}$ \\
\hline 112 & $348.83 \mathrm{Aa}$ & $341.74 \mathrm{ABa}$ & $281.67 \mathrm{Ab}$ & $441.20 \mathrm{Aa}$ & $409.96 \mathrm{Aa}$ \\
\hline 168 & $299.92 \mathrm{ABa}$ & $320.90 \mathrm{ABa}$ & $270.53 \mathrm{Aa}$ & $317.04 \mathrm{BCa}$ & $315.47 \mathrm{Ba}$ \\
\hline 224 & $282.14 \mathrm{ABa}$ & $278.94 \mathrm{BCa}$ & $207.57 \mathrm{ABb}$ & $226.96 \mathrm{CDb}$ & $262.32 \mathrm{BCa}$ \\
\hline 280 & $215.60 \mathrm{BCa}$ & $220.36 \mathrm{Ca}$ & $157.41 \mathrm{Bb}$ & 174.24 Db & $238.71 \mathrm{BCa}$ \\
\hline 336 & $175.11 \mathrm{Ca}$ & $192.88 \mathrm{Ca}$ & $145.66 \mathrm{Bb}$ & $142.85 \mathrm{Db}$ & $181.02 \mathrm{Ca}$ \\
\hline
\end{tabular}

${ }^{\mathrm{z}}$ Nitrogen use efficiency (NUE) was estimated as the ratio of the marketable fruit yield to the amount of $\mathrm{N}$ supplied during the production season.

${ }^{\mathrm{y}}$ Means followed by the same uppercase letter within a column, and means followed by the same lowercase letter within a row are not significantly different at $P \leq 0.05$ according to Tukey's test.

$\mathrm{FL} / \mathrm{BE}=$ 'Florida 47' grafted onto 'Beaufort'; FL/MU = 'Florida 47' grafted onto 'Multifort'; FL = nongrafted 'Florida 47 '

combinations of scions and rootstocks. In the present study, the two interspecific tomato hybrid rootstocks demonstrated an overall similar yield improvement. Although the rootstocks used are well known for their high resistance to several soilborne diseases, the increased yields observed here with fumigated soils could be attributed primarily to the vigorous characteristics of the rootstocks. The positive scion-rootstock interactions would have improved plant growth and development. Yield enhancement from grafting, even in a low disease pressure, has been reported previously with solanaceous and cucurbitaceous vegetables (Leonardi and Giuffrida, 2006; Proietti et al., 2008; Ruiz et al., 1997). In this study, fruit yields were similar for self-grafted (FL/FL) and nongrafted (FL) plants under the recommended irrigation regime and $\mathrm{N}$ rate (data not shown), thus reinforcing the suggestion that yield increase could be attributed mainly to the specific rootstocks used rather than the grafting process per se. Lykas et al. (2008) reported an increase of tomato yield resulting from selfgrafting in a greenhouse hydroponic study. However, it was unclear how consistent the self-grafting effect was because their study was not repeated in a second season. Nevertheless, it has been suggested that the growth and yield enhancement in grafted vegetable plants are largely contributed by the use of selected rootstocks rather than the grafting process per se (Davis et al., 2008; Lee and Oda, 2003; Lee et al., 2010).

In general, data here showed that increases in both fruit number per plant and average fruit weight contributed to the overall improvement of marketable fruit yield from grafted plants. These results concur with some previous reports (Lee and Oda, 2003; Passam et al., 2005), but Di Gioia et al. (2010) did not observe a significant change in yield components as a result of grafting. In our study, the cull fruit yield (small, immature, and/or damaged fruit) did not differ significantly between grafted and non-grafted tomato plants (data not shown). However, the percentage of cull fruit out of the total harvest was reduced in grafting treatments by $28 \%$ on average relative to the non-grafted plants. Underlying mechanisms inherent to growth vigor and yield enhancement by grafted plants are often attributed to enhanced nutrient and water uptake (Rouphael et al., 2008; Ruiz et al., 1997) and improved endogenous hormone status (Aloni et al., 2010; Lee et al., 2010).

Seasonal variation of the irrigation and $N$ rate effects. Under the two irrigation regimes tested in this study, increasing $\mathrm{N}$ rate significantly increased fruit yields of both grafted and non-grafted tomato plants to a maximum amount, which then did not show any significant increase with higher levels of $\mathrm{N}$ application. These results were consistent with previous studies by Hebbar et al. (2004), Scholberg et al. (2000), and Topcu et al. (2007) using tomatoes grown under diverse environmental conditions. The influence of irrigation regime and $\mathrm{N}$ rate on total and marketable yields varied between 2010 and 2011 seasons. In nificantly higher fruit yields as compared with the $100 \%$ irrigation regime. In contrast, in 2011, yields under the $100 \%$ irrigation tended to be higher than those with the $50 \%$ irrigation at $\mathrm{N}$ rates above $224 \mathrm{~kg} \cdot \mathrm{ha}^{-1}$. The inconsistent results over these two seasons could be largely related to the variation of environmental conditions, especially the rainfall. The 2010 growing season had a higher level of rainfall than 2011, particularly during the plant reproductive stage. This period corresponded to the prime period of fruit development during which the nutrients applied through fertigation accounted for $\approx 60 \%$ of the total nutrient supply after transplanting. Florida's sandy soils are characterized by poor water holding capacity and are more prone to nitrate $\left(\mathrm{NO}_{3}{ }^{-}\right)$leaching (Simonne et al., 2004, 2006). With the heavier rainfall in $2010, \mathrm{NO}_{3}^{-}$leaching problem in sandy soils at the experimental site could have been worse and therefore reduced $\mathrm{N}$ uptake by plants. A study by Zotarelli et al. (2009a) in Citra, FL, reported similar interannual differences in tomato yields when rainfall was greater along with higher temperatures in the middle of the growing season. Improving irrigation scheduling based on soil moisture 2010 , the $50 \%$ irrigation regime led to sig- sensors and crop needs will help reduce nitrate leaching in field tomato production in sandy soils (Simonne et al., 2010; Zotarelli et al., 2009b). In this study, significant yield improvement was generally not oberved with $\mathrm{N}$ rates above $168 \mathrm{~kg} \cdot \mathrm{ha}^{-1}$. This is in line with results reported by Zotarelli et al. (2009a) who in a three-year study did not find any significant difference in fruit yields of the same tomato cultivar Florida 47 in north Florida in response to three $\mathrm{N}$ rates $\left(176,220\right.$, and $\left.330 \mathrm{~kg} \cdot \mathrm{ha}^{-1}\right)$. With the same tomato cultivar (non-grafted) and experimental site as our study, Poh et al. (2011) observed a difference in yields as a result of interannual environmental disparities. In one season, these authors obtained fruit yields of 44, 43, and $49 \mathrm{Mg} \cdot \mathrm{ha}^{-1}$ at 134, 179, and 224 $\mathrm{kg} \mathrm{N} / \mathrm{ha}$, respectively, with a significant difference between the highest $\mathrm{N}$ rate and the other two lower $\mathrm{N}$ rates, whereas such a trend was not found in the other season. In another field study in central Florida on the specialty tomato cultivar Tasti-Lee, a significantly higher total marketable yield was found at $307 \mathrm{~kg} \mathrm{~N} / \mathrm{ha}$ as compared with those at 229 and $268 \mathrm{~kg} \mathrm{~N} / \mathrm{ha}$ over two seasons (Santos et al., 2010).

Grafting influence on irrigation water and nitrogen use efficiency. Regardless of the irrigation levels, 'Florida 47' grafted onto the two rootstocks was more efficient in water use for fruit production compared with the non-grafted plants. These results concur with previous reports on rootstock effects on the iWUE relative to marketable fruit yield. According to Lykas et al. (2008), grafting with 'He-mans' rootstock improved WUE (measured as amount of harvested fruit per volume of transpired water) of greenhouse-grown 'Big Red' tomato by $\approx 112 \%$, although selfgrafted 'Big Red' also exhibited a similar increase. Improvement of WUE was also observed by Rouphael et al. (2008) on miniwatermelon under field conditions. The enhanced WUE found in grafted plants in these studies was mainly the result of the improvement of fruit yields rather than reduced water use. In both 2010 and 2011 trials, the 100\% irrigation regime resulted in a decrease in iWUE as opposed to the $50 \%$ irrigation regime despite the use of grafting with rootstocks. This indicates that the full irrigation regime probably caused an excess in water supply, which did not favor fruit yield development. Similar findings were reported previously by Rouphael et al. (2008) on mini-watermelon, Cabello et al. (2009) on melon, and Kirnak et al. (2002) on eggplant. The enhancement in WUE in reduced irrigation regimes is often attributed to various adaptive physiological mechanisms, which involve changes in water relations and gas exchange (Bloch et al., 2006; Rajabi et al., 2009). It is suggested that under drought stress, water loss associated with plant carbon fixation can be reduced (Bloch et al., 2006). Increase in WUE of plants under reduced water supply may also be related to certain morphological changes in plants such as deeper root systems and canopy modification (Zhang et al., 1998). 
In addition to improved iWUE, grafting with appropriate rootstocks may also induce greater diversity in terms of NUE as compared with non-grafted plants. Our data showed that when averaged over irrigation regimes and $\mathrm{N}$ rates, grafted plants were more $\mathrm{N}$ use efficient in marketable fruit production by $\approx 35 \%$ and $42 \%$ compared with non-grafted plants in 2010 and 2011, respectively. An increase of NUE relative to yield by $12 \%$ in grafted melon was reported by Colla et al. (2010) in comparison with non-grafted plants. In another study on mini-watermelon, Colla et al. (2011) observed a 38\% increase in NUE of grafted plants in contrast to nongrafted plants. Similar to the improvement of iWUE, higher NUE observed with grafted plants in this study was associated with greater yields in grafted plants than nongrafted plants. Although grafting, irrigation regime, and $\mathrm{N}$ rate showed relatively consistent effects on iWUE between 2010 and 2011, their influence on NUE varied with the production season. The significant interaction effect of irrigation regime and $\mathrm{N}$ application on NUE in 2011 suggested differential effects of $\mathrm{N}$ rates under different irrigation regimes. Except for the lowest $\mathrm{N}$ rate, increasing $\mathrm{N}$ rates under both irrigation regimes resulted in reduced efficiency of $\mathrm{N}$ use for yield production. Only one tomato scion cultivar was used in this study. Future research will need to involve more scions and rootstocks to identify the scion-rootstock interactions and specific traits of rootstocks in relation to the improvement of iWUE and NUE in grafted tomato plants.

\section{Conclusions}

This study demonstrated that use of grafted plants could significantly improve fruit yields in field production of drip-irrigated tomato in sandy soils in Florida. The increase of marketable yields resulted from both more fruit per plant and higher average fruit weight. Grafting with the two interspecific tomato hybrid rootstocks used here also led to significant enhancement in efficiency of water and $\mathrm{N}$ use. Overall, the two rootstocks performed similarly. Moreover, variation in environmental conditions, particularly rainfall, contributed greatly to the influence of irrigation and $\mathrm{N}$ application on fruit yields. Future studies are warranted to explore the $\mathrm{N}$ requirement for grafted tomato production under field conditions, because data here indicate that these needs are likely to differ from those of nongrafted tomatoes.

\section{Literature Cited}

Aloni, B., R. Cohen, L. Karni, H. Aktas, and M. Edelstein. 2010. Hormonal signaling in rootstockscion interactions. Sci. Hort. 127:119-126.

Barrett, C.E., X. Zhao, and R. McSorley. 2012. Grafting for root-knot nematode control and yield improvement in organic heirloom tomato production. HortScience 47:614-620.

Bausher, M. 2009. Commercial tomato rootstock performance when exposed to natural populations of root-knot nematodes in Florida. HortScience 44:1021 (abstr.).
Bloch, D., C.M. Hoffmann, and B. Märländer. 2006. Impact of water supply on photosynthesis, water use and carbon isotope discrimination of sugar beet genotypes. Eur. J. Agron. 24: 218-225.

Cabello, M.J., M.T. Castellanos, F. Romojaro, C. Martínez-Madrid, and F. Ribas. 2009. Yield and quality of melon grown under different irrigation and nitrogen rates. Agr. Water Mgt. 96:866-874.

Colla, G., C.M. Cardona Suárez, M. Cardarelli, and Y. Rouphael. 2010. Improving nitrogen use efficiency in melon by grafting. HortScience 45:559-565.

Colla, G., Y. Rouphael, C. Mirabelli, and M. Cardarelli. 2011. Nitrogen-use efficiency traits of mini-watermelon in response to grafting and nitrogen-fertilization doses. J. Plant Nutr. Soil Sci. 174:933-941.

Davis, A.R., P. Perkins-Veazie, Y. Sakata, S. López-Galarza, J.V. Maroto, S.G. Lee, Y.C. Huh, Z. Sun, A. Miguel, S.R. King, R. Cohen, and J.M. Lee. 2008. Cucurbit grafting. Crit. Rev. Plant Sci. 27:50-74.

Di Gioia, F., F. Serio, D. Buttaro, O. Ayala, and P. Santamaria. 2010. Influence of rootstock on vegetable growth, fruit yield and quality in 'cuore di bue', an heirloom tomato. J. Hort. Sci. Biotechnol. 85:477-482.

Fernández-García, N., V. Martínez, A. Cerdá, and M. Carvajal. 2004. Fruit quality of grafted tomato plants grown under saline conditions. J. Hort. Sci. Biotechnol. 79:9951001.

Florida Automated Weather Network. 2011. Archived weather data for Live Oak. 15 July 2011. $<$ http://fawn.ifas.ufl.edu/data/reports/>.

Hartz, T.K. and G.J. Hochmuth. 1996. Fertility management of drip-irrigated vegetables. HortTechnology 6:168-171.

Hebbar, S.S., B.K. Ramachandrappa, H.V. Nanjappa, and M. Prabhakar. 2004. Studies on NPK drip fertigation in field grown tomato (Lycopersicon esculentum Mill.). Eur. J. Agron. 21:117-127.

Hochmuth, G.J. 1992. Fertilizer management for drip-irrigated vegetables in Florida. HortTechnology 2:27-32.

Kato, T. and H. Lou. 1989. Effects of rootstock on the yield, mineral nutrition and hormone level in xylem sap in eggplant. J. Jpn. Soc. Hort. Sci. 58:345-352.

Kirnak, H., I. Tas, C. Kaya, and D. Higgs. 2002. Effects of deficit irrigation on growth, yield and fruit quality of eggplant under semi-arid conditions. Aust. J. Agr. Res. 53:1367-1373.

Lee, J.M. 1994. Cultivation of grafted vegetables. I. Current status, grafting methods, and benefits. HortScience 29:235-239.

Lee, J.M. and M. Oda. 2003. Grafting of herbaceous vegetable and ornamental crops. Hort. Rev. 28:61-124.

Lee, J.M., C. Kubota, S.J. Tsao, Z. Bie, P.H. Echevarria, L. Morra, and M. Oda. 2010 Current status of vegetable grafting: Diffusion, grafting techniques, automation. Sci. Hort. 127: 93-105.

Leonardi, C. and F. Giuffrida. 2006. Variation of plant growth and macronutrient uptake in grafted tomatoes and eggplants on three different rootstocks. Eur. J. Hort. Sci. 71:97-101.

Locascio, S.J. 2005. Management of irrigation for vegetables: Past, present, and future. HortTechnology 15:482-485.

López-Pérez, J.A., M. Le Strange, I. Kaloshian, and A.T. Ploeg. 2006. Differential response of Mi gene-resistant tomato rootstocks to root-knot nematodes (Meloidogyne incognita). Crop Prot. 25:382-388.
Lykas, C., C. Kittas, and A. Zambeka. 2008. Water and fertilizers use efficiency in grafted and non grafted tomato plants on soilless culture. Acta Hort. 801:1551-1555.

McAvoy, T., J.H. Freeman, S.L. Rideout, S.M. Olson, and M.L. Paret. 2012. Evaluation of grafting using hybrid rootstocks for management of bacterial wilt in field tomato production. HortScience 47:621-625.

Natural Resources Conservation Service. 2006. Soil survey of Suwannee County, Florida. 24 July 2011. <http://soildatamart.nrcs.usda.gov/ Manuscripts/FL121/0/Suwannee.pdf>.

Olson, S.M., W.M. Stall, G.E. Vallad, S.E. Webb, T.G. Taylor, S.A. Smith, E.H. Simonne, E. McAvoy, and B.M. Santos. 2009. Tomato production in Florida, p. 291-312. In: Olson, S.M. and E. Simonne (eds.). Vegetable production handbook for Florida. IFAS, University of Florida, Gainesville, FL.

Passam, H.C., M. Stylianou, and A. Kotsiras. 2005. Performance of eggplant grafted on tomato and eggplant rootstocks. Eur. J. Hort. Sci. 70:130-134.

Pogonyi, Á., Z. Pék, L. Helyes, and A. Lugasi. 2005. Effect of grafting on the tomato's yield, quality and main fruit components in spring forcing. Acta Aliment. 34:453-462.

Poh, B.L., A. Gazula, E.H. Simonne, F. Di Gioia, R.C. Hochmuth, and M.R. Alligood. 2011. Use of reduced irrigation operating pressure in irrigation scheduling. I. Effect of operating pressure, irrigation rate, and nitrogen rate on drip-irrigated fresh-market tomato nutritional status and yields: Implications on irrigation and fertilization management. HortTechnology 21: 14-21.

Proietti, S., Y. Rouphael, G. Colla, M. Cardarelli, M. De Agazio, M. Zacchini, E. Rea, S. Moscatello, and A. Battistelli. 2008. Fruit quality of miniwatermelon as affected by grafting and irrigation regimes. J. Sci. Food Agr. 88:1107-1114.

Rajabi, A., E.S. Ober, and H. Griffiths. 2009. Genotypic variation for water use efficiency, carbon isotope discrimination, and potential surrogate measures in sugar beet. Field Crops Res. 112:172-181.

Rivard, C.L. and F.J. Louws. 2008. Grafting to manage soilborne diseases in heirloom tomato production. HortScience 43:2104-2111.

Rivard, C.L., S. O'Connell, M.M. Peet, and F.J. Louws. 2010. Grafting tomato with interspecific rootstock to manage diseases caused by Sclerotium rolfsii and southern root-knot nematode. Plant Dis. 94:1015-1021.

Rivard, C.L., S. O'Connell, M.M. Peet, R.M. Welker, and F.J. Louws. 2012. Grafting tomato to manage bacterial wilt caused by Ralstonia solanacearum in the southeastern United States. Plant Dis. 96:973-978.

Rouphael, Y., M. Cardarelli, G. Colla, and E. Rea. 2008. Yield, mineral composition, water relations, and water use efficiency of grafted mini-watermelon plants under deficit irrigation. HortScience 43:730-736.

Ruiz, J.M., A. Belakbir, I. López-Cantarero, and L. Romero. 1997. Leaf-macronutrient content and yield in grafted melon plants. A model to evaluate the influence of rootstock genotype. Sci. Hort. 71:227-234.

Santos, B.M., J.W. Scott, and M. Ramírez-Sánchez. 2010. In-row distances and nitrogen fertilization programs for 'Tasti-Lee' specialty tomato. HortTechnology 20:579-584.

Scholberg, J., B.L. McNeal, K.J. Boote, J.W. Jones, S.J. Locascio, and S.M. Olson. 2000. Nitrogen stress effects on growth and nitrogen accumulation by field-grown tomato. Agron. J. 92:159167. 
Schwarz, D., Y. Rouphael, G. Colla, and J.H. Venema. 2010. Grafting as a tool to improve tolerance of vegetables to abiotic stresses: Thermal stress, water stress and organic pollutants. Sci. Hort. 127:162-171.

Simonne, E., M. Dukes, G. Hochmuth, B. Hochmuth, D. Studstill, and A. Gazula. 2006. Monitoring nitrate concentration in shallow wells below a vegetable field. Proc. Fla. State Hort. Soc. 119:226-230.

Simonne, E., C. Hutchinson, J. DeValerio, R. Hochmuth, D. Treadwell, A. Wright, B. Santos, A. Whidden, G. McAvoy, X. Zhao, T. Olczyk, A. Gazula, and M. Ozores-Hampton. 2010. Current knowledge, gaps, and future needs for keeping water and nutrients in the root zone of vegetables grown in Florida. HortTechnology 20:143-152.

Simonne, E., D. Studstill, and R. Hochmuth. 2004. Understanding water movement in mulched beds on sandy soils: An approach to ecologically sound fertigation in vegetable production. Acta Hort. 700:173-178.

Stegemann, S. and R. Bock. 2009. Exchange of genetic material between cells in plant tissue grafts. Science 324:649-651.

Topcu, S., C. Kirda, Y. Dasgan, H. Kaman, M. Cetin, A. Yazici, and M.A. Bacon. 2007. Yield response and $\mathrm{N}$-fertiliser recovery of tomato grown under deficit irrigation. Eur. J. Agron. 26:64-70.

Valle, E.M., S.B. Boggio, and H.W. Heldt. 1998. Free amino acid composition of phloem sap and growing fruit of Lycopersicon esculentum. Plant Cell Physiol. 39:458461.

Yamasaki, A., M. Yamashita, and S. Furuya. 1994. Mineral concentrations and cytokinin activity in the xylem exudate of grafted watermelons as affected by rootstocks and crop load. J. Jpn. Soc. Hort. Sci. 62:817-826.

Zhang, J., X. Sui, B. Li, B. Su, J. Li, and D. Zhou. 1998. An improved water-use efficiency for winter wheat grown under reduced irrigation. Field Crops Res. 59:91-98.

Zotarelli, L., J.M. Scholberg, M.D. Dukes, R. Muñoz-Carpena, and J. Icerman. 2009a. Tomato yield, biomass accumulation, root distribution and irrigation water use efficiency on a sandy soil, as affected by nitrogen rate and irrigation scheduling. Agr. Water Mgt. 96:23-34.

Zotarelli, L., M.D. Dukes, J.M.S. Scholberg, R. Muñoz-Carpena, and J. Icerman. 2009b. Tomato nitrogen accumulation and fertilizer use efficiency on a sandy soil, as affected by nitrogen rate and irrigation scheduling. Agr. Water Mgt. 96:1247-1258. 